Journal of Engineering and Applied Sciences 14 (Special Issue 8): 10335-10340, 2019

ISSN: 1816-949X

(C) Medwell Journals, 2019

\title{
A Stepwise Regression Algorithm for Prognostication Draft Requirements of Disk Plough
}

\author{
Salim Almaliki, Majed Salih Himoud and Sadiq Jabar Muhsin \\ Department of Agricultural Machinery, University of Basrah, Basrah, Iraq
}

\begin{abstract}
Development of models for prediction draft requirements of disk plough contribute in improving their performance in the field. In this study, a mathematical models was developed to predict draft force requirements of disk plough under various field conditions. Field experiments were carried out at two levels of moisture content ( 8 and $21 \%$ ) two levels of cone index (550 and $980 \mathrm{kPa}$ ), three levels of tillage depth $(15,20$ and $25 \mathrm{~cm})$ and three levels of forward speed $\left(0.54,0.83\right.$ and $\left.1.54 \mathrm{msec}^{-1}\right)$ in a silty clay soil. A stepwise regression algorithm was utilized to extract models and to analyze results by using Design Expert Software. Results showed inconsiderable variation between the predicted and experimental values confirmed the thoroughness of this model in prognostication for draft force requirements of disk plough. The mathematical models analysis of variance demonstrated that all parameters had significant effect on draft force of disk plough. The draft force of disk plough increased by $11,19,46$ and $116 \%$ with increasing moisture content, cone index, forward speed and tillage depth, respectively. The interaction between forward speed and tillage depth had the most effect on draft force of disk plough.
\end{abstract}

Key words: Disk plough, stepwise regression algorithm, draft force, Design Expert Software, inconsiderable, requirements

\section{INTRODUCTION}

Tillage operation is the agricultural preparation of soil by mechanical agitation to provide favorable conditions for crop production. Which is consider as main function to prepare farmland for agriculture. Different implements were used to do tillage operation such as moldboard, disk plow, chisel plow and rotary plow. Each type of these is used for specific function and under various field conditions. For development of tillage equipment and made it work at optimum performance, many researchers were toward study of the effect of operational factors and soil condition on tillage implements. The importance achieved of this point led to development of several mathematical models for prediction of the performance of implements during tillage operations.

In the study of draft force, researchers have illustrated that increasing forward speed increases the depth of cut which is relative to increase in draft that caused much pulverizing of the soil surface and energy requirement of the implement (Nkakini, 2015; Babatunde, 2005; Harris and Smith 1999; Grisso et al., 1996). The tillage implements are vastly used by farmers as an elementary tillage equipment. Its performance evaluation is necessary in order to diminish the expenditure of the tillage operation (Arvidsson and Hillerstrom, 2010; Hosseinzadeh et al., 2011; Chen et al., 2004).

In the studies conducted to evolution the effect of Soil Moisture Content (SMC), Tillage Depth (TD) and
Operation Speed (OS) of the implement on draft force of moldboard plow (pull-type). The results revealed that the draft force decreased by increasing SMC and increased by increasing TD and OS. Moreover, TD had identical influence on draft force with increasing SMC (Rashidi et al., 2013; Almaliki, 2017).Draft force is considered as a pertinent measure of tractive performance parameters and influential factor in fuel consumption of tractor (Almaliki et al., 2016a, b). Tillage operation is one of the most operations consumed energy in the farm. Therefore, draft and power requirements are essential in order to determine the capability of the tractor that could be used for a specific implement. The draft required for a given implement will also be influenced by the soil conditions and the geometry of the tillage implement (Taniguchi et al., 1999; Naderloo et al., 2009; Olatunji and Davies, 2009). Arvidsson et al. (2004) studied the specific draft (force per cross sectional area of worked soil), energy use for moldboard plow, chisel plow and disc harrow at different soil conditions. They found that the specific draft was generally the highest for the chisel plow and the lowest for the moldboard plow and the disc harrow and referred that to the differences in implement geometry and mode of soil break-up.

Many researchers have been used various techniques for simulating draft force and they are analytical, empirical and numerical methods (Ahmadi, 2016; Almaliki et al., 2016a, b; Akbarnia et al., 2014; Al-Hamed et al., 2013). Sahu and Raheman (2006)

Corresponding Author: Salim Almaliki, Department of Agricultural Machinery, University of Basrah, Basrah, Iraq 
developed several models to predict draft for tillage tools based on soil condition, soil properties and implement width. Akbarnia et al. (2014) developed an Artificial Neural Network (ANN) Model with a back propagation learning algorithm to predict draft requirements of two winged share tillage tools in a loam soil. Kheiralla et al. (2004) formulated a draft force models for ploughs based on traveling speed and tillage depth. Overall objective of this study was to produce of a mathematical model for predicting draft force of disk plough under various field condition. Moreover, this research includes a comprehensive number of effectual parameters which leads to a holistic approach for achieving a realistic model.

\section{MATERIALS AND METHODS}

Tillage site: The field experiments were conducted in the experimental farm of Agricultural Machinery Department at University of Basrah located in (19" 30' 33 N 54" 47' $44 \mathrm{E}$, Basrah province, Iraq) as shown in Fig. 1. The soil at the experimental site has silty clay texture ( $49 \%$ silt, $20 \%$ sand and $31 \%$ clay).

Soil tests: Several soil samples from tillage site at depth levels of $15,20 \mathrm{~m}$ and $25 \mathrm{~cm}$ at different parts of the field were collected using a cylindrical core sampler, for measuring moisture content and bulk density. Collected samples were instantly put in plastic bags to conserve moisture during convey to the laboratory. Samples were weighted before and after drying in oven at $105^{\circ} \mathrm{C}$. Moisture content and bulk density were calculated from Eq. 1 and 2, respectively:

$$
\mathrm{MC}=\frac{\mathrm{WB}-\mathrm{WA}}{\mathrm{WB}} \times 100
$$

Where:

MC : Moisture content (\%)

WB : Wet weight of soil sample (g)

WA : Dry wet of soil sample (g)

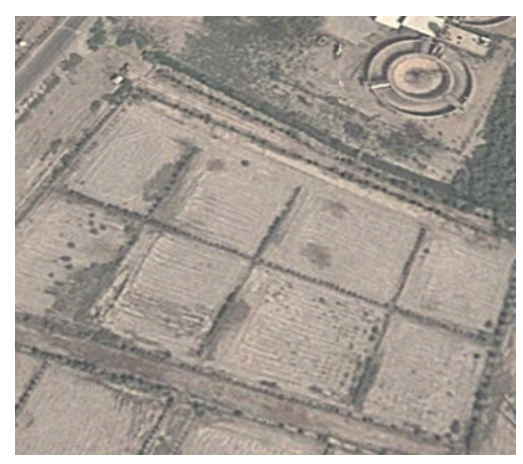

Fig. 1: Tillage site

$$
\mathrm{BD}=\mathrm{ms} / \mathrm{Vc}
$$

Where:

$\mathrm{BD}$ : Bulk density $\left(\mathrm{kgm}^{-3}\right)$

$\mathrm{ms}$ : Dry weight of soil in the cylinder $(\mathrm{kg})$

Vc : Cylinder volume $\left(\mathrm{m}^{3}\right)$

Cone Index explains the resistance to penetration into the soil per unit cone base area. The cone index and its gradient with respect to penetration depth have been used as a basis for predicting off-road vehicle performance. Cone index values were obtained by taking penetrometer readings at $5 \mathrm{~cm}$ increments to depths of $25 \mathrm{~cm}$ at several locations of the plots using a cone penetrometer according to ASABE Standards S313.2 with a cone base area of $130 \mathrm{~mm}^{2}$ and $30^{\circ}$ (Anonymous, 2009) (Table 1).

Tractor and implement: Two tractors were used in this research. The first tractor was a $55 \mathrm{~kW}$ case $\mathrm{IH} 71$ tractor produce by India which was used to provide energy for pulling the used plow in the experiments. The second tractor was Massey Ferguson 285 (56 kW) which was utilized for mounting the plows with it. The specifications of these tractors were showed in Table 2 . The experiments were carried out using conventional tillage system which includes a disk plough. The disk plough comprised of three disks. Diameter of each disk was $70 \mathrm{~cm}$. Tilt and disk angles for all disks were $35^{\circ}$ and $45^{\circ}$. The active width of the plow was $120 \mathrm{~cm}$. The maximum operating depth of the disks was about $30 \mathrm{~cm}$.

Experiment parameters: The experiments were carried out in the farm with various field conditions using three tractor forward speeds and three depths of disk plough. These parameters were used at two moisture contents levels and two cone indices of soil as shown in Table 3. All experiments had three replications resulting in a total of 108 tests.

Data acquisition system: The data acquisition system consisted of an Arduino electronic board and portable computer (laptop) linked via. a USB port. Data were sampled at $50 \mathrm{msec}$ intervals. The draft force of the disk plough for each experiment of the treatments was also registered based on the RNAM system (RNAM, 1995). The force exerted by the implement is measured by load cell in a strain gauge, namely, Wheatstone bridge arrangement. Draft was recorded in the measured distance $(20 \mathrm{~m})$ as well as the time taken to traverse the

Table 1: Corresponding calculated bulk density and moisture content at different cone index values

\begin{tabular}{lcr}
\hline Variables & $-\cdot-\cdot-\cdot-\cdot$ \\
\hline Moisture content $(\%)$ & 1015 & 21 \\
Bulk density $\left(\mathrm{kgm}^{-3}\right)$ & 550 & 980 \\
Cone index $(\mathrm{kPa})$ & & \\
\hline
\end{tabular}


Table 2: Specifications of used tractors in experiments

\begin{tabular}{lll}
\hline Specifications & Case IH 7 Model & Massey Ferguson 285 Model \\
\hline No. of cylinders & $4 \mathrm{CYL}$ & 4 CYL \\
Power (kW/hp) @ 2500 rpm & $75 / 55$ & $77 / 56$ \\
Max. torque (Nm @ rpm) & $242 \mathrm{Nm} @ 1500 \mathrm{rpm}$ & $248 @ 1300 \mathrm{rpm}$ \\
Fuel tank capacity & 62 & 120 \\
Transmission clutch & Mechanical & Mechanical \\
Total number of speeds & 8 forward, 2 reverse & 8 forward, 2 reverse \\
PTO speeds (rpm) & 540 & 540 \\
Wheelbase 2/4WD (mm) & $2160 / 2200$ & $2100 / 2290$ \\
Ground clearance under rear axle (mm) & 555 & 450 \\
Type size 2WD front/back & $16-7.50 / 30-16.9$ & $24-12.4 / 30-18.4$ \\
\hline
\end{tabular}

Table 3: Input parameters used in experiments

\begin{tabular}{lccc}
\hline $\begin{array}{l}\text { Moisture } \\
\text { content }(\%)\end{array}$ & $\begin{array}{c}\text { Cone index } \\
(\mathrm{kPa})\end{array}$ & $\begin{array}{c}\text { Depth } \\
(\mathrm{cm})\end{array}$ & $\begin{array}{c}\text { Forward speed } \\
\left(\mathrm{msec}^{-1}\right)\end{array}$ \\
\hline 6 & 550 & 15 & 0.54 \\
23 & 980 & 20 & 0.83 \\
- & - & 25 & 1.54 \\
\hline
\end{tabular}

distance. The drawbar load cell is an $\mathrm{S}$ shaped (Model H3-C3-3.0t-6B-D55 from Zemic with capacity of $30 \mathrm{kN}$ ). It is mounted between two tractors. The first one is a as puller case JX75T and the other one is Massey Ferguson (MF 285) as auxiliary. The auxiliary tractor pulls the implement-mounted tractor with the latter in neutral gear but with the implement in the operating position. For more accuracy, calibration of the load cell was fulfilled by applying known weights and recording the measured output strain. Recorded force data were considered as rolling resistance force of the auxiliary tractor wheels.

\section{RESULTS AND DISCUSSION}

For prognostation of draft requirements for disk plough, a total of 108 experiments were conducted under different field condition (moisture content, cone index, tillage depth and forward speed) for generating convenient models of draft force. The data were abbreviated by taking average of treatments. For choosing more robust and more authoritative models, a variety of several polynomial models were analyzed by using Design Expert Software.In order to optimize and reduce the number of nominee regressors, a stepwise regression algorithm, as a most widely used variable selection technique (Montgomery and Runger, 2014) was applied, resulting in the reduced models (Table 4).

Figure 2 demonstrated the correlation between actual and predicted values of draft force for disk plough under various field conditions. The inconsiderable variation between the predicted and experimental values confirmed the thoroughness of this model in prognostication for disk plow requirements. It can Also be noted, the internally studentized residuals vs. run number (Fig. 3) of the models are in the proper range.

For achive ANOVA table, Design Expert Software was used to determine the level of significance effects of
Table 4: Summary of statistics of reduced quadratic models

\begin{tabular}{lrll}
\hline Variables & Values & Variables & Values \\
\hline SD & 0.59 & $\mathrm{R}^{2}$ & 0.9731 \\
Mean & 9.36 & Adj R $^{2}$ & 0.9709 \\
CV\% & 6.26 & Pred R $^{2}$ & 0.9678 \\
PRESS & 40.65 & Adeq precision & 75.707 \\
\hline
\end{tabular}

Table 5: ANOVA table of draft force for disk plough

\begin{tabular}{lrrrl}
\hline Source & $\begin{array}{r}\text { Sum of } \\
\text { squares }\end{array}$ & df & F-values & $\begin{array}{l}\text { p-values } \\
\text { Prob }>\text { F }\end{array}$ \\
\hline Model & 1229.55 & 9 & 447.92 & $<0.0001$ \\
A-MC & 19.88 & 1 & 57.93 & $<0.0001$ \\
B-CI & 75.55 & 1 & 220.19 & $<0.0001$ \\
C-depth & 991.09 & 1 & 2888.40 & $<0.0001$ \\
D-speed & 84.28 & 1 & 276.34 & $<0.0001$ \\
MC-CI & 1.46 & 1 & 7.30 & 0.0329 \\
MC-speed & 1.23 & 1 & 2.67 & 0.0448 \\
CI-depth & 2.24 & 1 & 6.54 & 0.0121 \\
CI-speed & 3.04 & 1 & 8.86 & 0.0037 \\
Depth-speed & 1.81 & 1 & 5.27 & 0.0238 \\
\hline
\end{tabular}

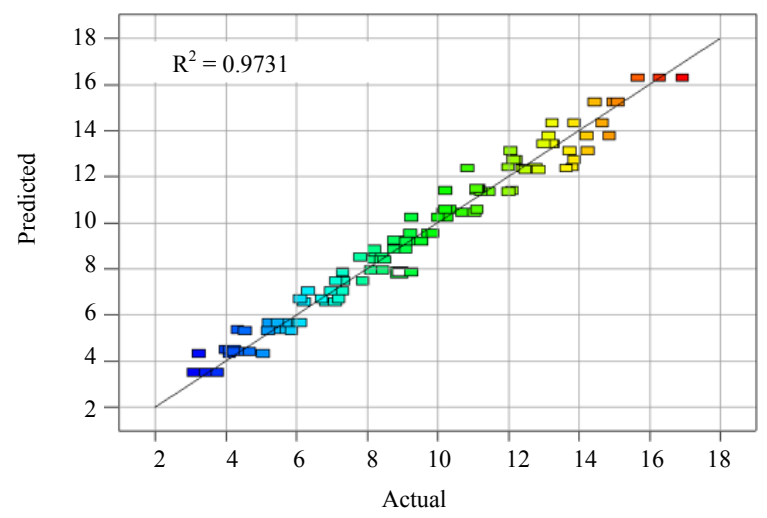

Fig. 2: Correlation of the actual and predicted draft force values for disk plough; Predicted vs. actual

the studied parameters (moisture content, cone index, tillage depth and the forward speed) on draft force of disk plow (Table 5). The results demonstrated that field parameters in this research had high significant effect on draft force of disk plow $(\mathrm{p}<0.0001)$. Moreover, the interaction between parameters had significant effect between them $(\mathrm{p}<0.05)$, except the interaction between moisture content and tillage depth. The best appropriate model for the prognostication draft force of disk plough under various field conditions is represented in Eq. 3. 
Design-Expert@ Software

Draft force

Color points by value of draft

force

$\int_{3.11}^{16.94}$

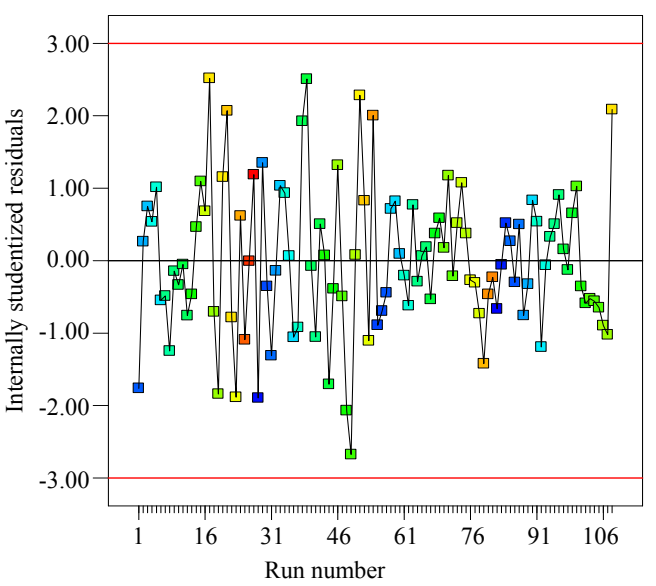

Fig. 3: The internally studentized residuals versus run number

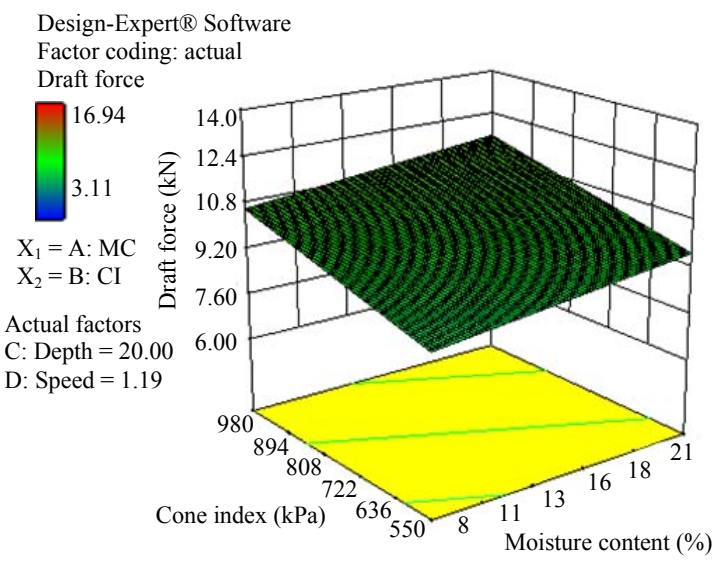

Fig. 4: The effect of moisture content and cone index and their interaction on draft force of disk plough

\section{Draft force (disk plough):}

\section{$-9.08+1.19^{*} \mathrm{MC}-1.11 \mathrm{E}-003{ }^{*} \mathrm{CI}+0.61^{*}$ \\ Depth $+3.95^{*}$ Speed $+0.37^{*} \mathrm{MC} *$ Speed + \\ $1.64 \mathrm{E}-004{ }^{*} \mathrm{CI}{ }^{*}$ Depth+1.87 E-003 ${ }^{*} \mathrm{CI}{ }^{*}$ \\ Speed-5.80*10E-004*Depth*Speed}

The results presented in Fig. 4 showed that the draft force of disk plough increased by $11 \%$ when moisture content incremented from $8-21 \%$. These results are in agreement with the findings of other researchers on moldboard plough (KarimiInchebron et al., 2012; Raper and Sharma, 2004). By increasing the cone index from $550-980 \mathrm{kPa}$, draft force of disk plough increased by $19 \%$. Cone index is a function of soil strength. Thus,

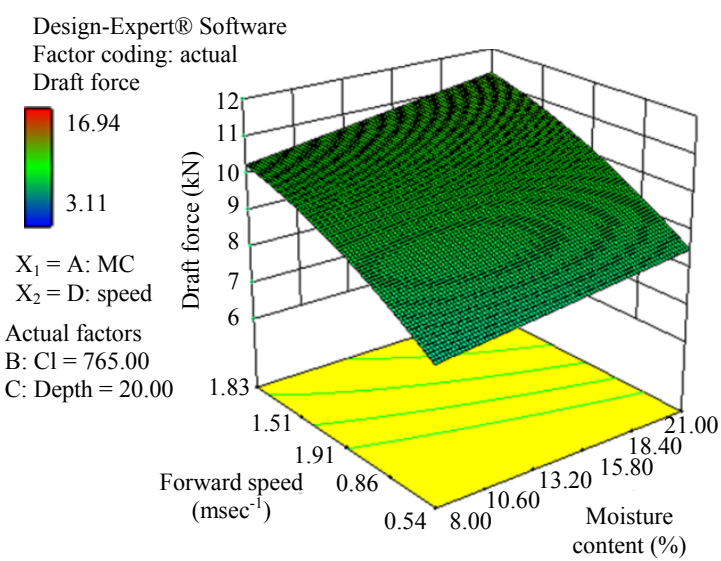

Fig. 5: The effect of moisture content and forward speed and their interaction on draft force of disk plough

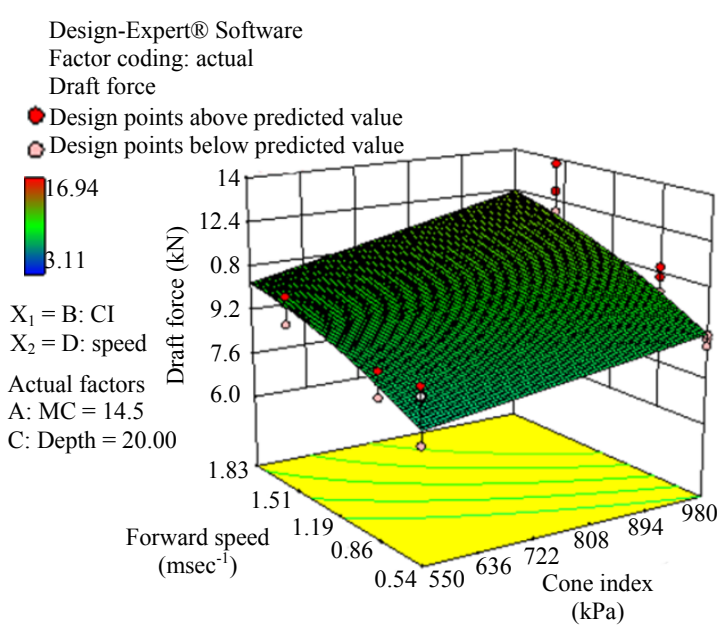

Fig. 6: The effect of cone index and forward speed and their interaction on draft force of disk plough

shear force of soil from disk plough would increment with rising cone index which led to increasing of draft force. The effect of interaction between moisture content and cone index led to increase draft force by $31 \%$.

Figure 5 showed the impact of forward speed and moisture content on draft force of disk plough. The draft force increased by $46 \%$ when forawd speed increased from $0.54-1.54 \mathrm{msec}^{-1}$. This return to increment of acceleration of shear force of soil particles. This is in agreement with the findings of the Rashidi (2013) and Almaliki (2017) in their study on moildboard plough. Also, the results indicated that interaction between forward speed and moisture content led to increase in draft force by $57 \%$. Moreover, the effect of interaction between cone index and forward speed on draft force was $68 \%$ (Fig. 6). The effect of tillage depth and cone index were illustrated in Fig. 7. Draft force increased by $116 \%$ when tillage depth increasing from $15-25 \mathrm{~cm}$. This is due 


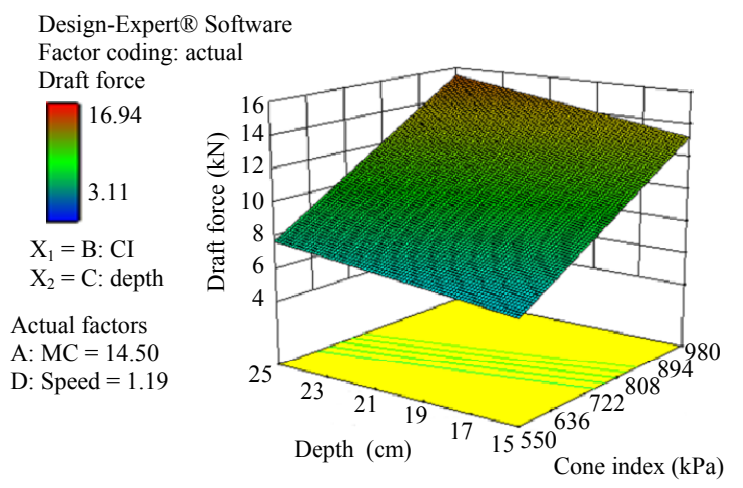

Fig. 7: The effect of cone index and tillage depth and their interaction on draft force of disk plough

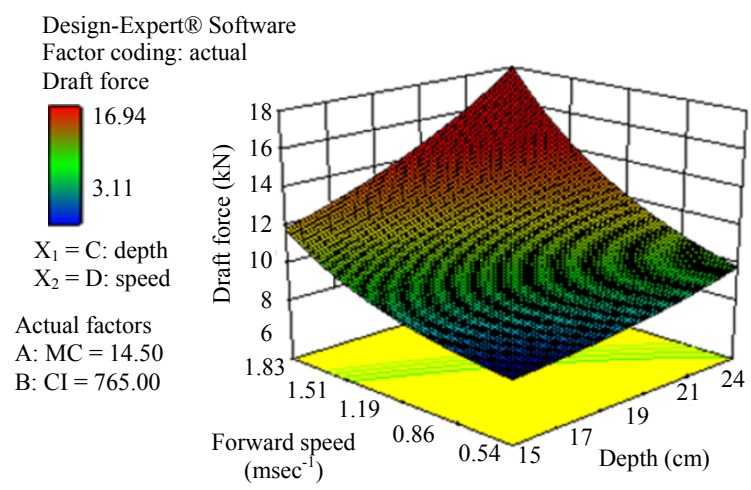

Fig. 8: The effect of cone index and tillage depth and their interaction on draft force of disk plough

to with increasing of tillage depth would cause a boost of shear soil, volume and mass, so that, more energy is require to shear the soil. Inaddition, incresing the soil mass collected around the disk plough causes the side compression on the disk plough, consequently the rubbing between runner and groove surface increases. These results are in agreement with the findings of other researchers (KarimiInchebron et al., 2012; Gilandeh et al., 2006). While the impact of interaction between tillage depth and cone index on draft force was $150 \%$. The combined effect of forward speed and tillage depth on draft force was $200 \%$ (Fig. 8). Which consider the biggest impact on draft force of disk plough. From the aforementioned, the most factor influctual on draft force of disk plough was tillage depth followed by forward speed, cone index and moisture content.

\section{CONCLUSION}

This study represents Design Expert Software Model for prognostication draft force of disk plough under different field conditions. This study represents Design Expert Software Model for prognostication draft force of disk plough under different field conditions. In order to optimize and reduce the number of candidate regressors, a stepwise regression algorithm used variable selection technique. The results demonstrated that there is a little difference between the predicted and actual values that confirmed the accuracy of this model in predicting the draft force of disk plow under various field conditions. ANOVA table illustrated high significant effect in draft force of disk plow with an increase in tillage depth, forward speed, cone index and moisture content. Furthermore, the results showed a significant effect between interactions of these parameters except the interaction between tillage depth and moisture content. Also, the results showed that the most effective parameter in draft force is the tillage depth, followed by the forward speed, cone index and moisture content.

\section{REFERENCES}

Ahmadi, I., 2016. Development and evaluation of a draft force calculator for moldboard plow using the laws of classical mechanics. Soil Tillage Res., 161: 129-134.

Akbarnia, A., A. Mohammadi, F. Farhani and R. Alimardani, 2014. Simulation of draft force of winged share tillage tool using artificial neural network model. Agric. Eng. Intl. CIGR. J., 16: 57-65. 
Al-Hamed, S.A., M.F. Wahby, S.M. Al-Saqer, A.M. Aboukarima and A.A. Sayedahmed, 2013. Artificial neural network model for predicting draft and energy requirements of a disk plow. J. Anim. Plant Sci., 23: 1714-1724.

Almaliki, S., 2017. Development and evaluation of models for MF-285 tractor performance parameters using computational intelligence techniques. Ph.D Thesis, University of Tehran, Tehran, Iran.

Almaliki, S., R. Alimardani and M. Omid, 2016b. Artificial neural network based modeling of tractor performance at different field conditions. Agric. Eng. Intl. CIGR. J., 18: 262-274.

Almaliki, S., R. Alimardani and M. Omid, 2016a. Fuel consumption models of MF285 tractor under various field conditions. Agric. Eng. Intl. CIGR. J., 18: 147-158.

Anonymous, 2009. ASAE/ASABE D497.6: Agricultural machinery management data. American Society of Agricultural and Biological Engineers, St. Joseph, Michigan, USA. https://www. techstreet. $\mathrm{com} /$ standards/asae-asabe-d497-6? product_id $=175$ 6870

Arvidsson, J. and O. Hillerstrom, 2010. Specific draught, soil fragmentation and straw incorporation for different tine and share types. Soil Tillage Res., 110: 154-160.

Arvidsson, J., T. Keller and K. Gustafsson, 2004. Specific draught for moldboard plough, chisel plough and disc harrow at different water contents. Soil Tillage Res., 79: $221-231$.

Babatunde, O.O., 2005. Effect of tilt and disc angles on the depth and width of cut of disc plough paper presented at the Nigerian Branch of the International Soil Tillage. Proceedings of the Research Organization Seminar, July 14, 2005, National Centre for Agricultural Mechanization, Ilorin, Nigeria, pp: 1992-1992.

Chen, Y., F.V. Monero, D. Lobb, S. Tessier and C. Cavers, 2004. Effects of six tillage methods on residue incorporation and crop performance in a heavy clay soil. Trans. ASAE., 47: 1003-1010.

Gilandeh, Y.A., A. Khalilian, R. Alimardani, A.R. Keyhani and S.H. Sadati, 2006. A comparison of energy requirements of uniform-depth and variable-depth tillage as affected by travel speed and soil moisture. Iran. J. Agric. Sci., 37: 573-583.

Grisso, R.D., M. Yasin and M.F. Kocher, 1996. Tillage implement forces operating in Silty clay loam. Trans. ASAE., 39: 1977-1982.

Harris, P. and M. Smith, 1999. Farm Machinery and Equipment. McGraw-Hill Education, New York, USA., Pages: 87.
Hosseinzadeh, B., A. Shirneshan and H. Zareiforoush, 2011. The effect of different types of tillage on soil's physical, mechanical and biological properties. Res., 3: $25-29$.

KarimiInchebron, A., S.R.M. Seyedi and R.T. Koloor, 2012. Investigating the effect of soil moisture content and depth on the draught, specific draught and drawbar power of a light tractor. Intl. Res. J. Appl. B. Sci., 3: 2289-2293.

Kheiralla, A.F., A. Yahya, M. Zohadie and W. Ishak, 2004. Modelling of power and energy requirements for tillage implements operating in Serdang sandy clay loam, Malaysia. Soil Tillage Res., 78: 21-34.

Montgomery, D.C. and G.C. Runger, 2014. Applied Statistics and Probability for Engineers. 6th Edn., John Wiley \& Sons Inc., Hoboken, New Jersey, USA., ISBN-13:9781118539712, Pages: 836.

Naderloo, L., R. Alimadani, A. Akram, P. Javadikia and H.Z. Khanghah, 2009. Tillage depth and forward speed effects on draft of three primary tillage implements in clay loam soil. J. Food Agric. Environ., 7: 382-385.

Nkakini, S.O., 2015. Draught force requirements of a disc plough at various tractor forward speeds in loamy sand soil, during ploughing. Intl. J. Adv. Res. Eng. Technol., 6: 52-68.

Olatunji, O.M. and R.M. Davies, 2009. Effect of weight and draught on the performance of disc plough on sandy loam soil. J. Applied Sci. Eng. Technol., 1: 22-26.

RNAM, 1995. RNAM test codes and procedures for farm machinery. Regional Network for Agricultural Machinery, RNAM, Technical Series No. 12, Bangkok, Thailand.

Raper, R.L. and A.K. Sharma, 2004. Soil moisture effects on energy requirements and soil disruption of subsoiling a coastal plain soil. Trans. ASAE., 47: 1899-1905.

Rashidi, M., I. Najjarzadeh, B. Jaberinasab, S.M. Emadi and M. Fayyazi, 2013. Effect of soil moisture content, tillage depth and operation speed on draft force of moldboard plow. Middle East J. Sci. Res., 16: 245-249.

Sahu, R.K. and H. Raheman, 2006. Draught prediction of agricultural implements using reference tillage tools in sandy clay loam soil. Biosyst. Eng., 94: 275-284.

Taniguchi, T., J.T. Makanga, K. Ohtomo and T. Kishimoto, 1999. Draft and soil manipulation by a moldboard plow under different forward speed and body attachments. Trans. Am. Soc. Agric. Biol. Eng., 4215171521. 